\title{
Boundary conditions of an active West Antarctic subglacial lake: implications for storage of water beneath the ice sheet
}

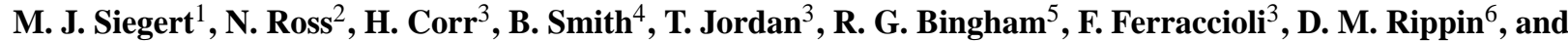 \\ A. Le Brocq ${ }^{7}$ \\ ${ }^{1}$ Bristol Glaciology Centre, School of Geographical Sciences, University of Bristol, Bristol, BS8 1SS, UK \\ ${ }^{2}$ School of Geography, Politics and Sociology, Newcastle University, Newcastle upon Tyne, NE1 7RU, UK \\ ${ }^{3}$ British Antarctic Survey, Cambridge CB3 OET, UK \\ ${ }^{4}$ Applied Physics Lab, Polar Science Center, University of Washington, Seattle, WA 98105, USA \\ ${ }^{5}$ School of GeoSciences, University of Edinburgh, Edinburgh EH8 9XP, UK \\ ${ }^{6}$ Environment Department, University of York, York YO10 5DD, UK \\ ${ }^{7}$ Geography, College of Life and Environmental Sciences, University of Exeter, Exeter EX4 4RJ, UK
}

Correspondence to: M. J. Siegert (m.j.siegert@bristol.ac.uk)

Received: 21 May 2013 - Published in The Cryosphere Discuss.: 24 June 2013

Revised: 16 October 2013 - Accepted: 13 November 2013 - Published: 3 January 2014

\begin{abstract}
Repeat-pass ICESat altimetry has revealed 124 discrete surface height changes across the Antarctic Ice Sheet, interpreted to be caused by subglacial lake discharges (surface lowering) and inputs (surface uplift). Few of these active lakes have been confirmed by radio-echo sounding (RES) despite several attempts (notable exceptions are Lake Whillans and three in the Adventure Subglacial Trench). Here we present targeted RES and radar altimeter data from an "active lake" location within the upstream Institute Ice Stream, into which at least $0.12 \mathrm{~km}^{3}$ of water was previously calculated to have flowed between October 2003 and February 2008. We use a series of transects to establish an accurate depiction of the influences of bed topography and ice surface elevation on water storage potential. The location of surface height change is downstream of a subglacial hill on the flank of a distinct topographic hollow, where RES reveals no obvious evidence for deep $(>10 \mathrm{~m})$ water. The regional hydropotential reveals a sink coincident with the surface change, however. Governed by the location of the hydrological sink, basal water will likely "drape" over topography in a manner dissimilar to subglacial lakes where flat strong specular RES reflections are measured. The inability of RES to detect the active lake means that more of the Antarctic ice sheet bed may contain stored water than is currently appreciated. Variation in ice surface elevation data sets leads to significant alteration in calculations of the local flow of basal
\end{abstract}

water indicating the value of, and need for, high-resolution altimetry data in both space and time to establish and characterise subglacial hydrological processes.

\section{Introduction}

Over the last ten years, our appreciation of basal hydrology in Antarctica has changed significantly. In the most recent inventory, Wright and Siegert (2012) collated evidence for 379 Antarctic subglacial lakes. Most of these $(\sim 250)$ are evidenced solely by discrete and distinct radio wave reflections from flat ice-water interfaces, using ice penetrating radio-echo sounding (RES). A few have been interpreted from flat ice sheet surfaces derived from a large region of floating ice (Bell et al., 2006, 2007). The remainder (numbering 124) have been established from repeat-pass satellite altimetric measurements of ice surface changes interpreted as evidence of water flowing into, and discharge from, "active" subglacial lakes (Smith et al., 2009). In some instances, RES data from a subglacial lake have been combined with repeat-pass altimetry, revealing compelling evidence for a substantial and active basal hydrological system in Antarctic ice streams (Christianson et al., 2012; Horgan et al., 2012). In one case, subglacial water discharge beneath Byrd Glacier, inferred from satellite altimetry, has been shown to 
coincide with an increase in measured ice surface velocity (Stearns et al., 2008). In addition, Scambos et al. (2011) used ICESat altimetry to reveal how rapid localised surface elevation change on the Antarctic Peninsula caused the drainage of a previously unknown subglacial lake. While most surface elevation changes have been measured close to the ice sheet margin, satellite altimetric evidence of basal water flow in the centre of East Antarctica (Wingham et al., 2006; McMillan et al., 2013) points to a potentially highly connected basal hydrological system linking large stores of water beneath the ice divide through fast flowing ice streams to the ice margin (Wright et al., 2012).

Several altimetrically derived subglacial lakes have numerous repeat-pass transects, which define accurately both lake outline and the loss/gain of water (e.g. Lake Whillans, Fricker et al., 2007). However, around half of the "active lake" inventory (Smith et al., 2009) is comprised of evidence for losses/gains of subglacial water from fewer than five transects, often just two and occasionally only one. In such cases, interpretation of discrete ice surface height changes as "active lakes" beneath the ice is plausible yet, given the paucity of data, inconclusive. Other explanations could include migration of "packets" of basal water (or sediment), as postulated by Gray et al. (2005) rather than volume loss/gain in distinct lake locations, or even the surface manifestation in changes to basal drag (Sergienko et al., 2007). As it is not known whether proposed "active lakes" drain completely before refilling (see e.g. Evatt et al., 2006; Wingham et al., 2006; Pattyn, 2008; Fowler, 2009), they are potentially ephemeral features. In both the Aurora and southern Wilkes subglacial basins, airborne RES data were acquired at the locations of proposed "active lakes" (Wright et al., 2012, 2014). Based on available data, no classic bright, flat and strong radio-wave reflections characteristic of deepwater lakes have been found to coincide with the locations of the "active lakes". In a few cases, "active lakes" were found to coincide with radio reflections showing one or two of these traits (e.g. Lake Mercer in the Siple Coast of West Antarctica; Fricker et al., 2007; Carter et al., 2007). Explanations for this mismatch include both the inability of radar to detect subglacial lakes under certain glaciological conditions (e.g. surface crevasses, or warm, $>-10^{\circ} \mathrm{C}$, ice), and a lack of water during the time of RES data acquisition. Furthermore, for all "active lakes", surrounding physiographical information that might help to understand how water flows into and out of a region cannot be detected using satellite altimetry alone.

Here we present targeted RES and radar altimeter data from an 'active lake' within the upstream Institute Ice Stream in West Antarctica, named "Institute E2". These data are coupled with ICESat ice surface measurements to ascertain evidence for basal water, local and regional basal topography and hydrological potential. In doing so, we reveal how the subglacial system can store and route basal water without the build-up of deep-water lakes, and demonstrate the ability of (and necessity for) high-resolution surface altimetry and RES to detect and understand such a system.

\section{Geophysical methods and data}

Institute E2 was defined by two tracks of ICESat repeatpass altimeter data (October 2003 and February 2008), during which the surface elevation rose by up to $\sim 5.5 \mathrm{~m}$. Notwithstanding alternative explanations for ice surface height changes (noted above), the available data reveal a discrete monopole dome of uplift explicable as a consequence of the isolated build-up of basal water. Based on the ICESat data, Smith et al. (2009) defined a simple polygon of the lake outline. According to calculations by Smith et al. (2009), the lake experienced a gain in water of $0.12 \mathrm{~km}^{3}$ and, according to the most recent data, was still gaining water at the end of 2008 (Figs. 2 and 3). The centre of the lake (as defined by the ICESat-inferred polygon) was used to define the location of a deep field camp on the Institute Ice Stream where, in the austral summer of 2010/2011, a RES campaign to measure basal topography and conditions of the Institute and Möller Ice Streams was undertaken (Ross et al., 2012). As the camp was positioned just a few $\mathrm{km}$ from the central lake coordinate, input/output survey flights were organised such that numerous RES transects were recovered from the lake at a variety of orientations. The survey geometry also led to RES data being acquired from the immediately surrounding regions, at a flight line spacing of $\sim 7.5 \mathrm{~km}$ (Fig. 1).

The RES equipment used was a coherent system with a carrier frequency of $150 \mathrm{MHz}$, a bandwidth of $12 \mathrm{MHz}$ and a pulse-coded waveform acquisition rate of $312.5 \mathrm{~Hz}$. Aircraft position was obtained from differential GPS. Surface elevation of the ice sheet was derived from radar altimeter terrainclearance measurements, with an accuracy of $\pm 1 \mathrm{~m}$. Doppler processing was used to migrate radar-scattering hyperbola at the bed in the along-track direction. The onset of the received bed echo was picked in a semi-automatic manner using PROMAX seismic processing software. The post-processed data rate was $6.5 \mathrm{~Hz}$, giving a spatial sampling interval of $\sim 10 \mathrm{~m}$. The travel time in the near-surface firn layer is taken as the sum of two components; solid ice and an air gap. When calculating ice thickness we used a nominal value of $10 \mathrm{~m}$ to correct for the firn layer. A spatial variation in density affects the equivalent air gap, however, and this could account for variations across the survey area in the order of $\pm 3 \mathrm{~m}$. This error is small relative to the overall error budget, however, which is dominated by the uncertainty in the overall ice thickness, estimated to be in the order of $\pm 1 \%$ (see methods section in Ross et al., 2012, for details of the calculation).

To calculate basal power returns, the RES data were processed by unfocused SAR; a coherent integration over the returns from a section of the first Fresnel zone. This processing workflow is distinct from the Doppler processing described above, and was necessary to maintain the true 

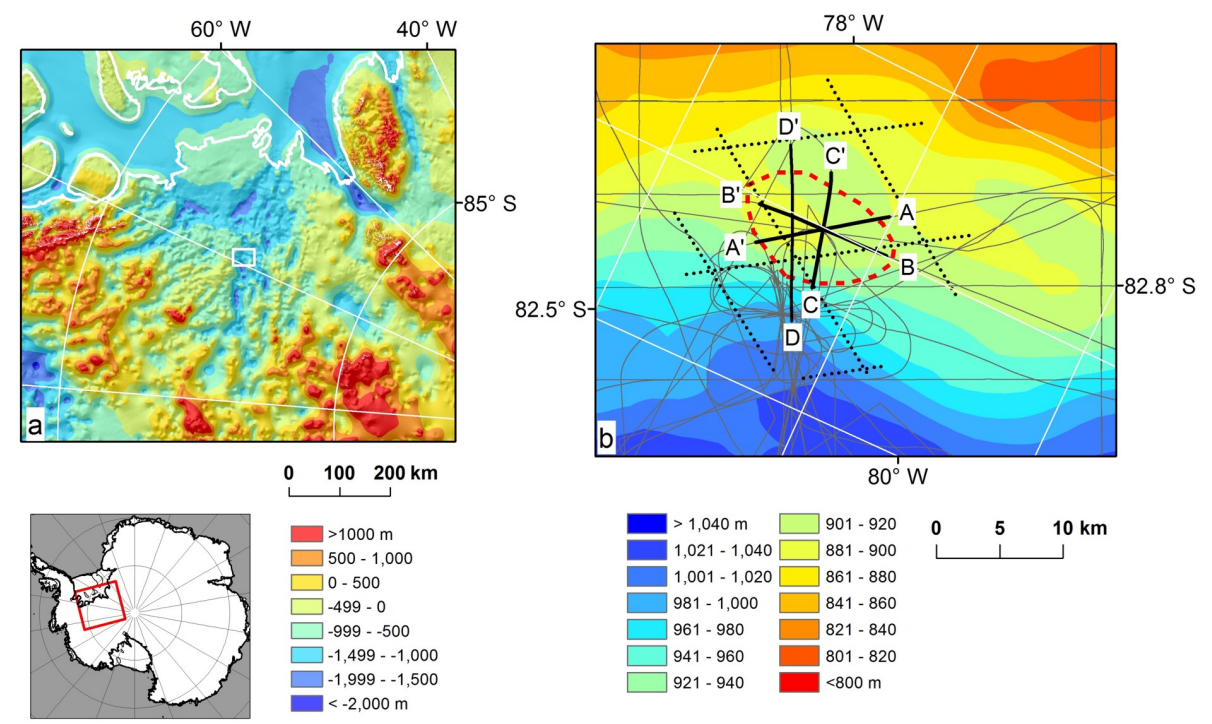

Fig. 1. (a) BEDMAP2 subglacial topography of the Institute Ice Stream region (with insert for study region in West Antarctica) (Fretwell et al., 2013). (b) Ice surface elevation with RES (grey lines) (Ross et al., 2012) and ICESat transects (black dotted lines) over and around Institute E2 (red dashed line), as delineated by Smith et al. (2009). RES lines in black, and labelled A-A', B-B', C-C' and D-D' refer to RES transects provided in Figs. 7 and 8. To assist comparison with Fig. 2, ICESat lines are oriented such that those closest to the $80^{\circ}$ W longitude are also closest to the Easting's axis in Fig. 2.

return power of the signal. The window length was chosen to be $\sim 50 \mathrm{~m}$ within which the peak value of the basal reflector power was picked. The signal power was then compensated for differences in path length, transmitted output, and dielectric absorption. A nominal average two-way absorption of $3.0 \mathrm{~dB} / 100 \mathrm{~m}$ was applied. This value was based on predictions of radar attenuation in Antarctica (Matsuoka et al., 2012), previous radar studies undertaken using the same equipment, and approximate calibration against the flat icewater interface radar returns from Ellsworth Subglacial Lake (Woodward et al., 2010). Reducing the rate of dielectric absorption increases the relative basal powers in shallower ice, but does not adversely affect the general distribution of received RES strength (i.e. calculations of regions with relatively high reflectivity are insensitive to variation around the likely absorption rate). Finally, an estimated system performance figure of $200 \mathrm{~dB}$ was subtracted from the result.

Measurement of ice thickness, subtracted from surface elevation (Fig. 1) yields subglacial topography (Fig. 4a). Assuming water is driven by gravity and overburden pressure of ice according to Shreve (1972), the bed and ice surface elevations can be used to calculate the hydrological potential (Fig. 4b), which through definition of the hydro-potential surface can deliver hydrological pathways (assuming the bed is wet everywhere). Finally, the basal radio-echo power returns, when normalised (i.e. corrected for englacial absorption and geometry spreading) to account for ice thickness, can provide information on basal conditions (Fig. 5). The radar altimeter data (and indeed RES data for bed elevations) were gridded, using the ArcGIS topo-2-raster function, and used to define the ice surface elevation around Institute E2. The ice surface elevations were compared with the most recent digital elevation model compilation of Antarctica (Bamber et al., 2009), and revealed significant (10-20 m) differences in elevation at a number of locations, most notably over the centre of Institute E2 (as defined by the lake outline polygon) (Fig. 6). We believe our surface elevation is more accurate over and around Institute E2 than Bamber et al.'s (2009) satellite-derived ice surface because of the greater density of airborne versus satellite tracks in this region and the fact that the airborne data were acquired within a short survey window of no more than 3 weeks (as opposed to several years).

The absolute elevations of ICESat (up to late 2008) and aircraft radar altimeter (December/January 2010/2011) data were compared to confirm the differences observed above were not due to significant basal water exchanges between the data acquisition dates. Because the aircraft radar has a coarser vertical resolution than ICESat, and because a fraction of the radar energy penetrates the snow surface before returning to the transmitter, there are potential offsets between the radar-estimated and ICESat elevations. Where radar tracks cross ICESat profiles, both inside and outside the boundary of Institute E2, the differences between the ICESat and radar elevations are typically on the order of $0.5 \mathrm{~m}$, although in a few places excursions of up to 2-3 m were measured. Given that the ice surface elevation uplift measured by ICESat was $\sim 6 \mathrm{~m}$ (Fig. 2), this suggests that while the lake did not drain or fill substantially between late 2008 and the 2010-2011 measurements, we cannot use the radar altimeter 


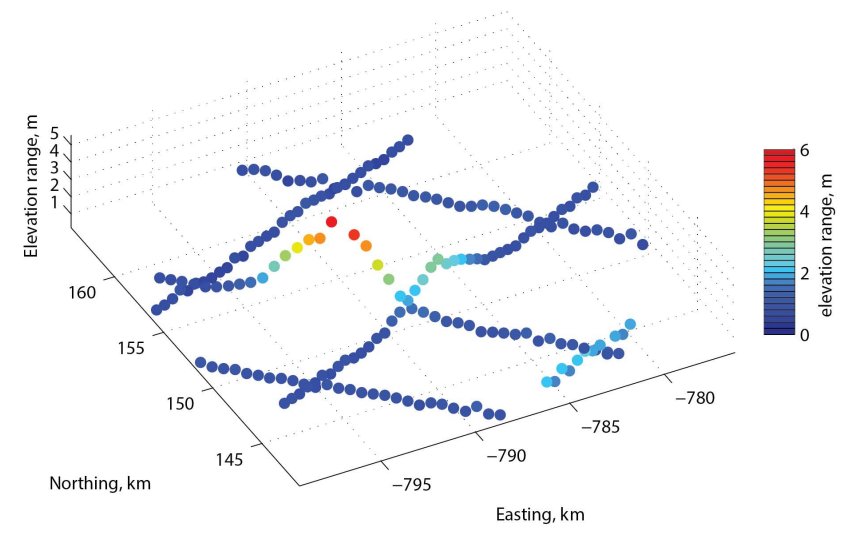

Fig. 2. Three-dimensional view of ICESat tracks (as noted in Fig. 1b) and the uplift detected between October 2003 and February 2008 (Smith et al., 2009). The ICESat lines are oriented such that those closest to the Easting's axis are also closest to the $80^{\circ} \mathrm{W}$ longitude in Figs. $1 \mathrm{~b}$ and $6 \mathrm{~b}$.

data to form a precise estimate of the 2009-2010/2011 volume change.

\section{Analysis}

\subsection{Ice surface elevation, bed topography and lake sensitivity}

Some of Institute E2 (as defined by the lake outline polygon) lies beneath a hydrological potential minima, and on the downslope flank of a topographic hill close to a sizeable valley, $\sim 2 \mathrm{~km}$ below the ice surface, at least $15 \mathrm{~km}$ in length and $\sim 1-2 \mathrm{~km}$ wide (Fig. 4; Supplement video). In many places, the influence of local topography on the flow of basal water is sufficiently large that subglacial basins are coincident with hydrological sinks and, hence, are topographically controlled subglacial lakes (Bell et al., 2006; Siegert et al., 2007). While it is possible for the hydrological sink to be displaced from obvious topographic basins (Christianson et al., 2012), what makes Institute E2's topographic situation unusual (compared with RES-defined subglacial lakes) is that its bed slope is aligned along the approximate direction of ice flow. This makes Institute E2 controlled as much by surface slope rather as bed topography (see Sect. 4) and, therefore, potentially susceptible to change if the ice surface elevation is adjusted. Obviously, one way of adjusting the ice surface is to fill the lake, thus the stability of Institute E2 may be related to its own growth. Since Institute E2 is not confined by topography, any discharge will only cease once the surface-slope-driven hydrological sink (Figs. 5, 7 and 8 ) is re-established. According to Wingham et al. (2006) this might not occur until the lake has completely discharged (although others point to restricted discharges; e.g. Fowler, 2009). Hence, Institute E2 may be ephemeral.

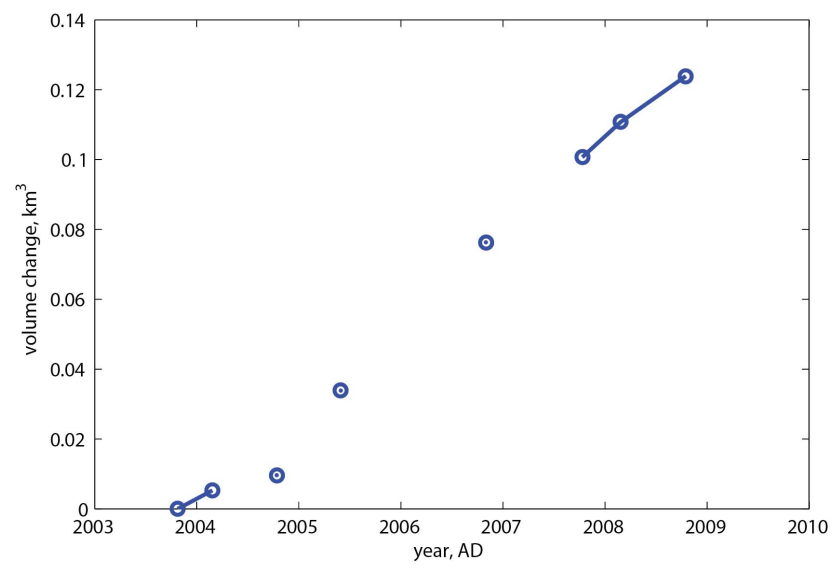

Fig. 3. Time-dependent change in the volume of Institute E2, using the method detailed in Smith et al. (2009) and ICESat surface elevation data between 2003 and 2009. Note that the data points are connected when intervening campaigns gave valid volume estimates. The data point at the end of 2008 is new to this paper (others being available in Smith et al., 2009).

The ice sheet in this region has only relatively recently relaxed from its Last Glacial Maximum form (perhaps within the last 500-1000 yr; Livingstone et al., 2013; Siegert et al., 2013). Given Institute E2's sensitivity to ice surface elevation, it is unlikely to predate the most recent glaciological setting, making it probably relatively young compared with some topographically controlled subglacial lakes (such as Ellsworth Subglacial Lake, Woodward et al., 2010).

\subsection{RES evidence of basal water}

We focus analyses on transects flown directly over the central coordinate of Institute E2 (Smith et al., 2009) in different orientations (Fig. 7), and along the approximate line of ice flow (Fig. 8). At the centre of Institute E2 (as defined by the lake outline polygon), there is little obvious qualitative evidence from RES for the presence of a deep-water subglacial lake (Figs. 5, 7 and 8). Subglacial lakes are traditionally characterised by RES as strong reflections (10-20 dB greater than surrounding bed) that are specular and flat, provided they are sufficiently deep (>10 m) (Oswald and Robin, 1973; Carter et al., 2007). RES from Institute E2 reveals bed reflections that are non-specular and non-flat, however. According to Gorman and Siegert (1999), VHF radio waves can penetrate through shallow pure-water bodies and, in six examples, they demonstrated how RES reflections from the ceiling and floor of a subglacial lake can interfere providing the water depth is $<10 \mathrm{~m}$. This can lead to RES reflections that are non-characteristic of deep subglacial lakes, and provides one explanation for why a sharp, mirror like interface is not observed in Institute E2 (in accordance with observations elsewhere, e.g. Langley et al., 2011; Welch et al., 2009). 

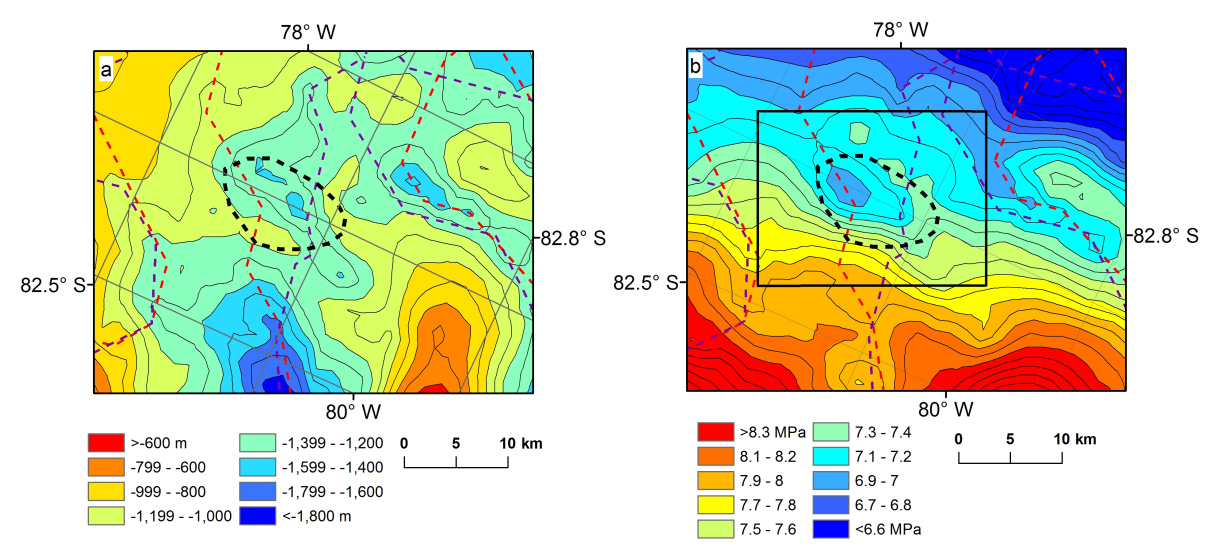

Fig. 4. Hydrological pathways (dashed lines) superimposed on (a) bed topography and (b) hydrological potential of the region surrounding Institute E2. The black box in (b) denotes the region depicted in Fig. 5. Two sets of hydrological pathways are given: red dashed lines, calculated using our aircraft ice surface altimeter data (Ross et al., 2012); and purple dashed lines, calculated using surface elevations from Bamber et al. (2009). Black dashed line delineates the approximate location of Institute E2, according to Smith et al. (2009). The direction of ice flow is predominantly from the bottom of the figures to the top.

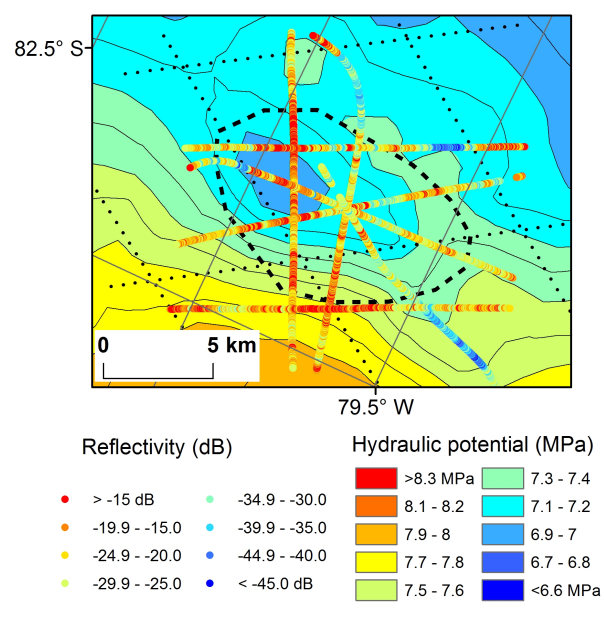

Fig. 5. Received RES strength (in $\mathrm{dB}$ ) from basal reflections along RES lines defined in Fig. 1 over and around Institute E2 (see Fig. 4b for location). The RES lines are superimposed onto the ice sheet hydro-potential (as in Fig. 4b). Also shown is the outline of Institute E2, as proposed by Smith et al. (2009) (black dashed line).

Relative RES power returns from Institute E2 have a noticeable spatial variability (Fig. 5). Over the centre coordinate of Institute E2 (Smith et al., 2009) they do not appear to be anomalously large. In both the centre of the topographic basin, and the centre of the hydrological potential sink (Fig. 4b) (which is offset to one side of the previously proposed area of Institute E2), relative basal power returns are generally $\sim 10-20 \mathrm{~dB}$ greater than from surrounding regions, however, although there is a noticeable along-track scatter (Fig. 5). Similarly strong RES returns, and therefore probably basal water, are also recorded from other regions in the survey area (Fig. 5). Conceptually, even if the water depths are very low (of the order of centimetres), enhanced
RES reflections should still be observed compared with a dry bed. Hence, it is possible that the distribution of water in Institute $\mathrm{E} 2$ is discontinuous. This opens the possibility for bed roughness to further reduce basal power returns, which may also help to explain the spatial complexity observed (Fig. 5). Noting the spatial correspondence between the surface elevation anomaly identified in the along-track ICESat data, enhanced reflectivity of the along-track RES data, and a minima in the gridded hydro-potential surface (Figs. 2 and 5), we suggest that the spatial extent of the lake is restricted to the region(s) of relatively high basal reflectivity. While assigning a lake outline is not possible with certainty, it is clear that the lake outline defined in Smith et al. (2009) is over-simplistic and, probably, too large.

An alternative explanation for the distribution of basal power returns is that they reflect defects in the RES system (either in data acquisition or processing). This is unlikely, given the system's ability to detect well-defined subglacial lake features in other regions of the wider survey, however (e.g. Ellsworth Subglacial Lake; Woodward et al., 2010).

\subsection{Flow of basal water}

According to Shreve (1972), based on our RES depiction of bed topography and radar measurement of ice surface elevation, water will be driven from the Institute E2 region toward the main trunk of the Institute Ice Stream (Fig. 4), where a larger, deeper subglacial basin exists, which (considering the thickness of ice within it) is also very likely to contain subglacial water (Fig. 1). This larger basin is part of a significant, topographically complex valley that routes water northwards toward the trunk of the Institute Ice Stream and, from there, to the Filchner Ronne Ice Shelf (Le Brocq et al., 2013). Differences between our radar measurements of ice surface elevation (acquired in less than 3 weeks) and Bamber et al.'s 

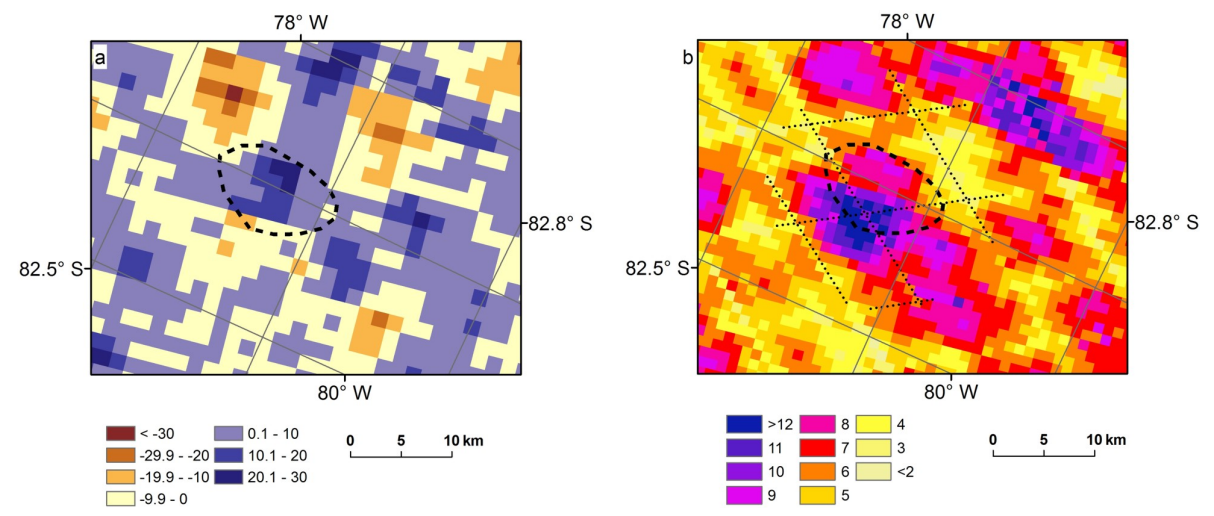

Fig. 6. Quantification (in meters) of errors in ice sheet surface elevation measurements. (a) Difference between Griggs and Bamber (2009) and this paper's (Fig. 1b) radar-altimeter surface elevations. (b) Map of the distribution of RMSE (root mean square error) in the Bamber et al. (2009) ice surface digital elevation model (DEM) (derived in this area exclusively from ICESat data) calculated using a multiple regression based on airborne validation data (adapted from Fig. 11 of Griggs and Bamber, 2009). Also shown is the outline of Institute E2, as proposed by Smith et al. (2009) (black dashed line), and ICESat lines (in b), which are oriented such that those closest to the $80^{\circ} \mathrm{W}$ longitude are also closest to the Easting's axis in Fig. 2.
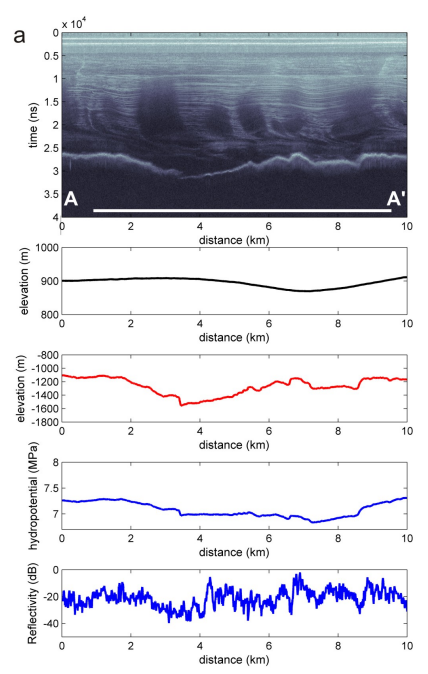
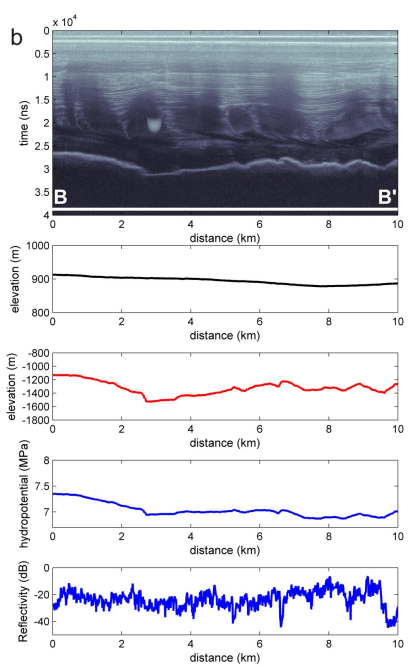
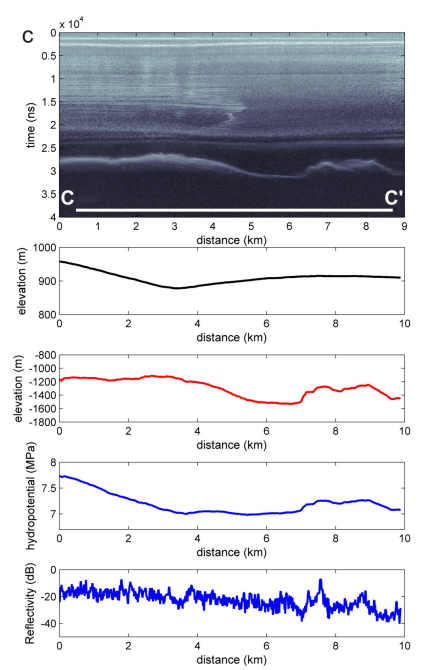

Fig. 7. RES transects centred on the "active" subglacial lake Institute E2. The locations of the transects are provided in Fig. 1b. (a) Transect A-A'. (b) Transect B-B'. (c) Transect C-C'. For each transect, the coverage of the ICESat-derived lake extent (after Smith et al., 2009) is shown as a white bar on the radargram. Beneath the radargrams graphs of ice surface elevation (black line), bed elevation (red line), basal hydropotential (upper blue line) and basal reflectivity (lower blue line) are provided.

(2009) DEM (collected over years), which are of the order of $10-20 \mathrm{~m}$ in places, result in local changes to the calculation of the expected route of basal water flow (Fig. 4b), demonstrating a high level of sensitivity in basal hydrology to ice surface elevation in this region. It is interesting to note that a $20 \mathrm{~m}$ error in ice surface elevation has the equivalent effect of $\mathrm{a} \sim 220 \mathrm{~m}$ error in the bed elevation; underlining the importance of accurate surface elevation data to quantify the flow of basal water (Wright et al., 2008).

The calculated routing of the subglacial water is also highly dependent upon the requirement to fill the hydropotential lows (i.e. "hydrological sinks") to make a hydro- logically workable surface as input for the flow routing algorithm. As the hydro-potential lows in Fig. 4b comprise a significant part of the study area they have a consequentially greater influence on our ability to determine the localised routing of the subglacial water than in studies of wider survey areas.

\section{Basal processes and data quality}

The measurement of a subglacial hydrological sink coincident with the ICESat-derived "active lake" is crucial to appreciating how water may both pond and discharge at the 

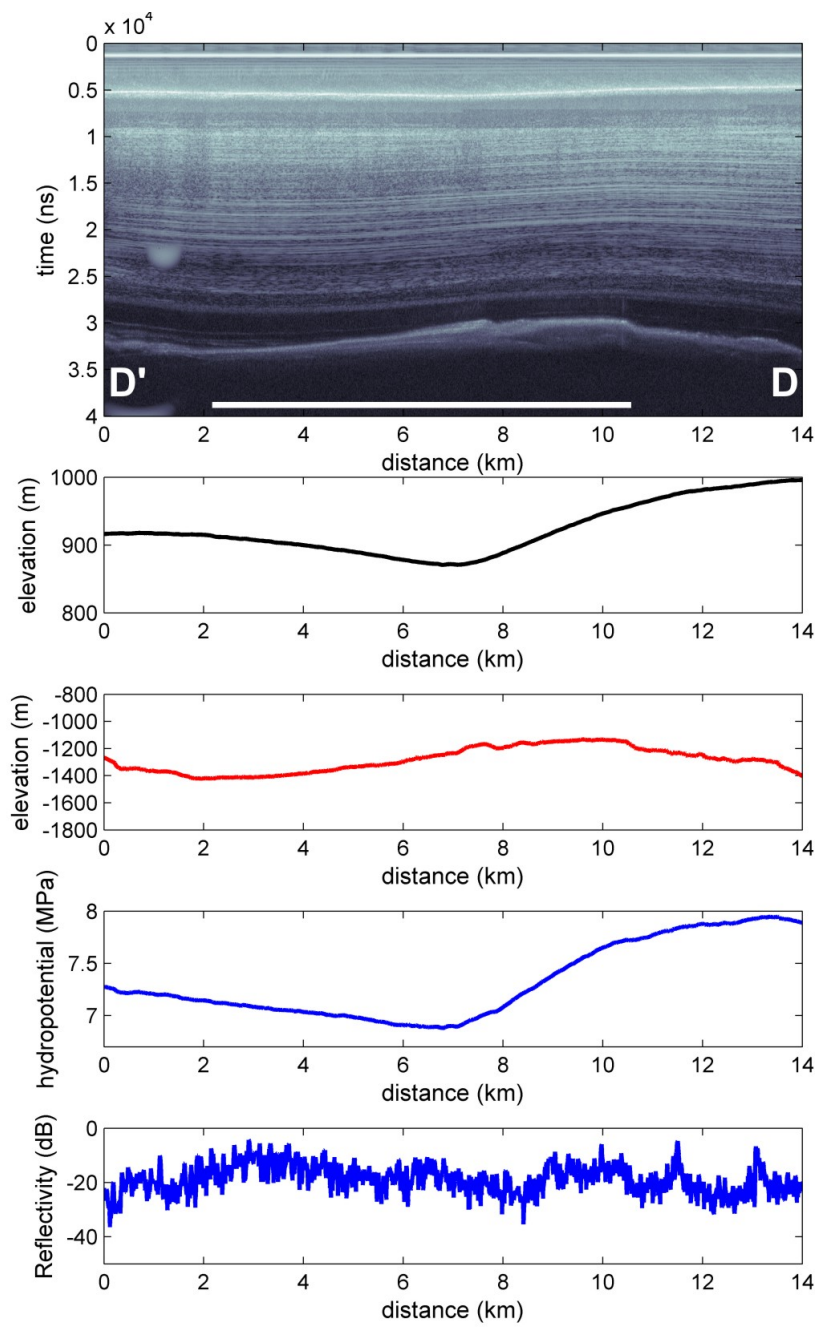

Fig. 8. RES transect D-D' (see Fig. 1b for location), along the approximate line of ice flow (from D to D'). The coverage of the ICESat-derived lake extent (after Smith et al., 2009) is shown as a white line on the radargram. Beneath the radargram graphs of ice surface elevation (black line), bed elevation (red line), basal hydropotential (upper blue line) and basal reflectivity (lower blue line) are provided.

site. From RES alone, it is likely that the existence of the subglacial lake would have been missed due to its possible thickness $(<10 \mathrm{~m})$ and/or its surface shape (i.e. not flat). Calculating the hydrological sink requires RES data, however, as does an appreciation of subglacial hydrological pathways. The example presented in this paper shows that RES alone may be both inadequate to fully comprehend the locations of "active lakes" yet crucial to appreciating the flow of water beneath the ice sheet. Currently, RES data are too sparse in Antarctica to accurately measure subglacial hydrological sinks other than those that are the consequence of large scale topography. Sub-km resolution in RES data are needed, and yet although such data allow enhanced appreciation of the subglacial environment (e.g. Bo et al., 2009; Woodward et al., 2010; King et al., 2009) the vast majority of the ice sheet base is sampled with transect separations normally $>5 \mathrm{~km}$, and often far greater. Consequently, although the broad potential subglacial flow of water is understood (e.g. Siegert et al., 2007), information on the flow of basal water is currently spatially insufficient to fully comprehend how "active" subglacial lakes exchange water and, ultimately, influence ice sheet dynamics.

While we think it unlikely that Institute E2 discharged all of its water in the short period $(\sim 1 \mathrm{yr})$ between the end of the ICESat time series and when the RES data were acquired (see Sect. 2), we cannot rule out entirely the possibility that the lake was relatively dry of water when the airborne data were collected, thus explaining the lack of evidence for a lake in the RES data. Whether a subglacial lake is able to drain completely has been the subject of several studies (Evatt et al., 2006; Wingham et al., 2006; Fowler, 2009). The pertinent issue being that a subglacial lake's ice seal theoretically becomes stronger as water is evacuated, thus potentially restricting discharges. It is also possible that the broader ice surface elevation may have changed recently, thus affecting the flow of basal water and our ability to calculate it correctly. These are serious data-related issues for the detection and understanding of basal water flow from active subglacial lakes, and their solution requires a time series of high-resolution data that is currently unavailable.

Institute E2 was chosen for investigation because of its location to a planned RES survey. Through this opportunity we have been able to reveal that the lake is unlikely to comprise deep (>10 m) water, and that it exists as a consequence of the interrelation between basal topography, ice flow and hydrology. Sergienko and Hulbe (2011) indicate that subglacial lakes may accumulate downstream of ice sheet "sticky spots", which may provide an explanation for why the lake grew in its present location. They show how water will infill on the lee side of subglacial obstacles, and the volume of water stored will be regulated by the rates of both water supply and subglacial freezing. Figure 8 , in which RES data were collected along the approximate line of ice flow, reveals that the hydro-potential minimum is positioned downstream of a subglacial hill, suggesting Sergionko and Hulbe's theory may be valid in Institute E2. Hence, although Institute E2 does not occupy a subglacial valley, it still may be controlled by subglacial topography to some degree.

As RES data from Institute E2 appear similar to many of the other 124 lakes identified using satellite altimetric changes (Wright et al., 2014), we should be confident that the mismatch between intuitive identification of subglacial lakes from RES and inferred subglacial hydrological changes from ice surface altimetry may be repeated in some (possibly many) other regions of Antarctica. The implication of the inability of RES to independently detect the locations of "active" subglacial lakes leads to the likelihood that much more of the Antarctic bed contains water than is currently appreciated from RES alone. 


\section{Summary and discussion}

Between October 2003 and November 2008, ICESat surface altimetry revealed a discrete zone of ice sheet uplift within the Institute Ice Stream, interpreted by Smith et al. (2009) to be due to the filling of a subglacial lake by at least $0.12 \mathrm{~km}^{3}$ of water (named Institute E2). In the austral summer of 2010-2011, an airborne geophysical survey of the Weddell Sea sector of West Antarctica targeted Institute E2 by flying a series of transects centred on the middle of the uplifted region (using a coordinate given in Smith et al., 2009). RES was used to measure subglacial topography and evidence for basal water. Airborne radar altimetry was used to measure ice sheet surface elevation. Institute E2 lies downstream of a subglacial hill, on the upstream flank of a major subglacial hollow. Sergienko and Hulbe (2011) predict basal water accumulation on the lee side of subglacial obstacles. Thus, although Institute E2 does not occupy a topographic basin, its location may still be influenced by the interrelation between basal water (production and flow) and topography. Using altimetry information to calculate how water may flow beneath the ice sheet reveals a hydropotential minimum coincident with the ICESat-derived anomaly of Institute E2 (but not the polygon as defined by Smith). RES also reveals relatively stronger (10-20 dB) basal reflections from beneath the hydropotential minimum than in adjacent regions, suggesting the presence of water, although considerable along-track scatter is also recorded. No classic RES reflections from a "deep-water" (>10 m) subglacial lake were observed, however. Based on these data, we consider Institute E2 is controlled as much by ice sheet surface slopes as by basal topography, making it potentially susceptible to small ice surface changes. Such changes may occur as a consequence of ponding by basal water, making the lake's stability potentially influenced by its own growth. As such, Institute E2 is likely to be ephemeral and shallow; we believe it unlikely that the water depth is greater than $10 \mathrm{~m}$.

Institute $\mathrm{E} 2$ is one of more than 100 active subglacial lakes detected through ice surface altimetric changes. They are scattered across the Antarctic ice sheet mostly, but not exclusively, located further toward the ice sheet margin than the divide. We have shown that RES alone is incapable of independently detecting Institute E2. Similar observations have been found for "active" lakes in both the Aurora (Wright et al., 2012) and southern Wilkes (Wright et al., 2014) subglacial basins. We therefore propose that considerably more basal water may be present in Antarctica than currently appreciated from RES. Given that the satellite altimetry is restricted to a short time series $(\sim 10 \mathrm{yr})$ and that evidence for significant "active" lake discharges are being discovered from analysis of new altimetric data sets (e.g. Flament et al., 2013; McMillan et al., 2013), our appreciation of the volume of stored basal water (Dowdeswell and Siegert, 1999; Wright and Siegert, 2011) is in need of upwards revision. Indeed, given recent RES evidence of widespread subglacial hydro- logical regimes in both East (Wright et al., 2012) and West (Schroeder et al., 2013) Antarctica, the level of stored water within these and comparable systems may be significantly underestimated.

\section{Supplementary material related to this article is available online at http://www.the-cryosphere.net/8/15/ 2014/tc-8-15-2014-supplement.zip.}

Acknowledgements. Funding was provided by UK NERC AFI grant NE/G013071/1. C. Robinson (Airborne Survey engineer), I. Potten and D. Cochrane (pilots) and M. Oostlander (air mechanic) are thanked for their invaluable assistance in the field. We also thank three referees, S. Carter, M. Wolovick and B. Csatho for their insightful and constructive reviews.

Edited by: E. Larour

\section{References}

Bamber, J. L., Gomez-Dans, J. L., and Griggs, J. A.: A new 1 km digital elevation model of the Antarctic derived from combined satellite radar and laser data - Part 1: Data and methods, The Cryosphere, 3, 101-111, doi:10.5194/tc-3-101-2009, 2009.

Bell, R. E., Studinger, M., Fahnestock, M. A., and Shuman, C. A.: Tectonically controlled subglacial lakes on the flanks of the Gamburtsev Subglacial Mountains, East Antarctica, Geophys. Res. Lett., 33, L02504, doi:10.1029/2005GL025207, 2006.

Bell, R. E., Studinger, M., Shuman, C. A., Fahnestock, M. A., and Joughin, I.: Large subglacial lakes in East Antarctica at the onset of fast-flowing ice streams, Nature, 445, 904-907, 2007.

Bo, S., Siegert, M. J., Mudd, S. M., Sugden, D. E., Fujita, S., Xiangbin, C., Yunyun, J., Xueyuan, T., and Yuansheng, L.: The Gamburtsev Mountains and the origin and early evolution of the Antarctic Ice Sheet, Nature, 459, 690-693, 2009.

Carter, S. P., Blankenship, D. D., Peters, M. E., Young, D. A., Holt, J. W., and Morse, D. L.: Radar-based subglacial lake classification in Antarctica, Geochem. Geophy. Geosy., 8, Q03016, doi:10.1029/2006GC001408, 2007.

Christianson, K., Jacobel, R. W., Horgan, H. J., Anandakrishnan, S., and Alley, R. B.: Subglacial Lake Whillans - Ice penetrating radar and GPS observations of a shallow active reservoir beneath a West Antarctic ice stream, Earth Planet. Sc. Lett., 331-332, 237-245, 2012.

Dowdeswell, J. A. and Siegert, M. J.: The dimensions and topographic setting of Antarctic subglacial lakes and implications for large-scale water storage beneath continental ice sheets, Geol. Soc. Am. Bull., 111, 254-263, 1999.

Evatt, G. W., Fowler, A. C., Clark, C. D., and Hulton, N. R. J.: Subglacial floods beneath ice sheets, Philos. T. R. Soc. A, 364, 1769-1794, 2006.

Fowler, A. C.: Dynamics of subglacial floods, P. Roy. Soc. A-Math. Phy., 465, 1809-1828, 2009.

Flament, T., Berthier, E., and Rémy, F.: Cascading water underneath Wilkes Land, East Antarctic Ice Sheet, observed using altimetry 
and digital elevation models, The Cryosphere Discuss., 7, 841871, doi:10.5194/tcd-7-841-2013, 2013.

Fretwell, P., Pritchard, H. D., Vaughan, D. G., Bamber, J. L., Barrand, N. E., Bell, R., Bianchi, C., Bingham, R. G., Blankenship, D. D., Casassa, G., Catania, G., Callens, D., Conway, H., Cook, A. J., Corr, H. F. J., Damaske, D., Damm, V., Ferraccioli, F., Forsberg, R., Fujita, S., Gim, Y., Gogineni, P., Griggs, J. A., Hindmarsh, R. C. A., Holmlund, P., Holt, J. W., Jacobel, R. W., Jenkins, A., Jokat, W., Jordan, T., King, E. C., Kohler, J., Krabill, W., Riger-Kusk, M., Langley, K. A., Leitchenkov, G., Leuschen, C., Luyendyk, B. P., Matsuoka, K., Mouginot, J., Nitsche, F. O., Nogi, Y., Nost, O. A., Popov, S. V., Rignot, E., Rippin, D. M., Rivera, A., Roberts, J., Ross, N., Siegert, M. J., Smith, A. M., Steinhage, D., Studinger, M., Sun, B., Tinto, B. K., Welch, B. C., Wilson, D., Young, D. A., Xiangbin, C., and Zirizzotti, A.: Bedmap2: improved ice bed, surface and thickness datasets for Antarctica, The Cryosphere, 7, 375-393, doi:10.5194/tc-7-3752013, 2013.

Fricker, H. A., Scambos, T., Bindshadler, R., and Padman, L.: An active subglacial water system in West Antarctica mapped from space, Science, 315, 1544-1548, 2007.

Gorman, M. R. and Siegert, M. J.: Penetration of Antarctic subglacial lakes by VHF electromagnetic pulses: Information on the depth and conductivity of subglacial water bodies, J. Geophys. Res., 104, 29311-29320, 1999.

Gray, L., Joughin, I., Tulaczyk, S., Spikes, V. B., Bindshadler R., and Jezek, K.: Evidence for subglacial water transport in the West Antarctic Ice Sheet through three-dimensional satellite radar interferometry, Geophys. Res. Lett., 32, L03501, doi:10.1029/2004GL021387, 2005.

Griggs, J. A. and Bamber, J. L.: A new 1 km digital elevation model of Antarctica derived from combined radar and laser data - Part 2: Validation and error estimates, The Cryosphere, 3, 113-123, doi:10.5194/tc-3-113-2009, 2009.

Horgan, H. J., Anandakrishnan, S., Jacobel, R. W., Christianson, K., Alley, R. B., Heeszel, D. S., Picotti, S., and Walter, J. I.: Subglacial Lake Whillans - Seismic observations of a shallow active reservoir beneath a West Antarctic ice stream, Earth Planet. Sc. Lett., 331-332, 201-209, 2012.

King, E., Hindmarsh, R., and Stokes, C.: Formation of mega-scale glacial lineations observed beneath a West Antarctic ice stream, Nat. Geosci., 2, 585-588, 2009.

Langley, K., Kohler, J., Matsuoka, K., Sinisalo, T., Scambos, T., Neumann, T., Muto, A., Winther, J.-G., and Albert, M.: Recovery Lakes, East Antarctica: Radar assessment of sub-glacial water extent, Geophys. Res. Lett., 38, L05501, doi:10.1029/2010GL046094, 2011.

Le Brocq, A., Ross, N., Griggs, J., Bingham, R., Corr, H., Ferroccioli, F., Jenkins, A., Jordan, T., Payne, A., Rippin, D., and Siegert, M. J.: Ice shelves record the history of channelised flow beneath the Antarctic ice sheet, Nat. Geosci., 6, 945-948, doi:10.1038/ngeo1977, 2013.

Livingstone, S. J., Clark, C. D., and Woodward, J.: Predicting subglacial lakes and meltwater drainage pathways beneath the Antarctic and Greenland ice sheets, The Cryosphere Discuss., 7, 1177-1213, doi:10.5194/tcd-7-1177-2013, 2013.

Matsuoka, K., MacGregor, J. A., and Pattyn, F.: Predicting radar attenuation within the Antarctic ice sheet, Earth Planet. Sc. Lett., 359-360, 173-183 doi:10.1016/j.epsl.2012.10.018, 2012
McMillan, M., Corr, H., Shepherd, A., Ridout, A., Laxon, S., and Cullen, R.: Three-dimensional mapping by CryoSat-2 of subglacial lake volume changes, Geophys. Res. Lett., 40, 43214327, doi:10.1002/grl.50689, 2013.

Oswald, G. K. A. and Robin, G. de Q.: Lakes beneath the Antarctic Ice Sheet, Nature, 245, 251-254, 1973.

Pattyn, F.: Investigating the stability of subglacial lakes with a full Stokes ice-sheet model, J. Glaciol., 54, 353-361, 2008.

Ross, N., Bingham, R. G., Corr, H., Ferraccioli, F., Jordan, T. A., Le Brocq, A., Rippin, D. M., Young, D., Blankenship, D. D., and Siegert, M. J.: Steep reverse bed slope at the grounding line of the Weddell Sea sector in West Antarctica, Nat. Geosci., 5, 393-396, doi:10.1038/ngeo1468, 2012.

Scambos, T. A., Berthier, E. and Shuman, C. A.: The triggering of sub-glacial lake drainage during the rapid glacier drawdown: Crane Glacier, Antarctic Peninsula, Ann. Glaciol., 52, 74-82, 2011.

Schroeder, D. M., Blankenship, D. D., and Young, D. A.: Evidence for a water system transition beneath Thwaites Glacier, West Antarctica, P. Natl. Acad. Sci., 110, 12225-12228, doi:10.1073/pnas.1302828110, 2013.

Sergienko, O. V. and Hulbe, C. L.: "Sticky spots" and subglacial lakes under ice streams of the Siple Coast, Antarctica, Ann. Glaciol., 52, 18-24, 2011.

Sergienko, O. V., MacAyeal, D. R., and Bindschadler, R. A.: Causes of sudden, short term changes in ice-stream surface elevation, Geophys. Res. Lett., 34, L22504, doi:10.1029/2007GL031775, 2007.

Shreve, R. L.: Movement of water in glaciers, J. Glaciol., 11, 205214, 1972.

Siegert, M. J., Le Brocq, A., and Payne A.: Hydrological connections between Antarctic subglacial lakes and the flow of water beneath the East Antarctic Ice Sheet, in: Glacial Sedimentary Processes and Products, edited by: Hambrey, M. J., Christoffersen, P., Glasser, N. F. and Hubbard, B. P, Special Publication \#39, International Association of Sedimentologists, 3-10, 2007.

Siegert, M. J., Ross, N., Corr, H., Kingslake, J., and Hindmarsh, R.: Late Holocene ice-flow reconfiguration in the Weddell Sea sector of West Antarctica, Quaternary Sci. Rev., 78, 98-107, 2013.

Smith, B. E., Fricker, H. A., Joughin, I. R., and Tulaczyk, S.: An inventory of active subglacial lakes in Antarctica detected by ICESat (2003-2008), J. Glaciol., 55, 573-595, 2009.

Stearns, L. A., Smith, B. E., and Hamilton, G. S.: Increased flow speed on a large East Antarctic outlet glacier caused by subglacial floods, Nat. Geosci., 1, 827-831, 2008.

Wingham, D. J., Siegert, M. J., Shepherd, A., and Muir, A. S.: Rapid discharge connects Antarctic subglacial lakes, Nature, 440, 1033-1036, 2006.

Woodward, J., Smith, A., Ross, N., Thoma, M., Grosfeld, C., Corr, H., King, E., King, M., Tranter, M., and Siegert, M. J.: Location for direct access to subglacial Lake Ellsworth: An assessment of geophysical data and modelling, Geophys. Res. Lett., 37, L11501, doi:10.1029/2010GL042884, 2010.

Welch, B. C., Jacobel, R. W., and Arcone, S.: First results from radar profiles collected along the US-ITASE traverse from Taylor Dome to South Pole (2006-2008), Ann. Glaciol., 50, 35-41, 2009.

Wright, A. and Siegert, M. J.: The identification and physiographical setting of Antarctic subglacial lakes: an update based on 
recent geophysical data, in: Subglacial Antarctic Aquatic Environments, edited by: Siegert, M., Kennicutt, C., Bindschadler, B., AGU Geophysical Monograph 192, Washington D.C., 9-26, 2011.

Wright, A. P. and Siegert, M. J.: A fourth inventory of Antarctic subglacial lakes, Antarct. Sci., 24, 659-664, doi:10.1017/S095410201200048X, 2012.

Wright A. P., Siegert, M. J., Le Brocq, A., and Gore, D.: High sensitivity of subglacial hydrological pathways in Antarctica to small ice sheet changes, Geophys. Res. Lett., 35, L17504, doi:10.1029/2008GL034937, 2008.
Wright, A. P., Young, D. A., Roberts, J. L., Dowdeswell, J. A., Bamber, J. L., Young, N., Le Brocq, A. M., Warner, R. C., Payne, A. J., Blankenship, D. D., van Ommen, T., and Siegert, M. J.: Evidence for a hydrological connection between the ice divide and ice sheet margin in the Aurora Subglacial Basin sector of East Antarctica, J. Geophys. Res.-Earth, 117, F01033, doi:10.1029/2011JF002066, 2012.

Wright, A. P., Young, D. A., Bamber, J. A., Dowdeswell, J. A., Payne, A. J., Blankenship, D. D., and Siegert, M. J.: Subglacial hydrological connectivity within the Byrd Glacier catchment, J. Glaciol., in press, 2014. 